\title{
CS-22 -El trabajo docente como referente observable de la gestión en las instituciones de educación superior
}

\author{
Teaching work as an observable reference of management in higher edu- \\ cation institutions
}

Erik Haidar Torres

Universidad Autónoma de Guadalajara, Tabasco

Autor a quien se dirige la correspondencia: ehaidart@uagtabasco.edu.mx

\section{Resumen}

T a complejidad de la educación superior y la imposibilidad de reducirla a materias simples y distintas, hace Linefectivo al enfoque burocrático para la organización del trabajo que aún prevalece y caracteriza a las instituciones de educación superior (IES) en México. Los esfuerzos por modificar esta perspectiva para la gestión han fracasado, entre otros factores, por la falta de referentes para la comprensión del paradigma de los sistemas, al no proveer de "anclaje" o conexos observables que den sentido y guíen las acciones de la alta dirección. Esencialmente se aborda este problema desde la modelación de los sistemas complejos y el uso de los sistemas de ecuaciones estructurales (SEM). Su alcance es explicativo, a partir de un estudio transversal de las variables relevantes, ex post facto y confirmatorio en el contexto de las dos IES particulares de Villahermosa, Tabasco, México de mayor tamaño.

Palabras claves: Gestión, modelación de sistemas complejos, instituciones de educación superior

\section{Abstract}

$\mathrm{T}$ he complexity of higher education and the impossibility of reducing it to simple and different courses, make ineffective bureaucratic approach to the organization of work that still prevails and characterizes the HEIs in Mexico. Efforts to change this perspective to management have failed, among other factors, by the lack of indicators for understanding the paradigm of complex systems, not providing observable "anchor" or that give meaning and leading the actions to management. Essentially this problem is approached from the modeling of complex systems and the use of structural equation systems (SEM). Its scope is explanatory, from a cross-sectional study of relevant variables, ex post facto and confirmatory in the context of the two larger HEIs in Villahermosa, Tabasco, Mexico. 